OPEN ACCESS

Edited by:

Kathleen P Hunt,

SUNY New Paltz, United States

Reviewed by:

Giles Dodson,

Massey University, New Zealand

Bridie McGreavy,

University of Maine, United States

${ }^{*}$ Correspondence:

Pete Bsumek

bsumekpk@jmu.edu

Specialty section:

This article was submitted to

Science and Environmental

Communication,

a section of the journal

Frontiers in Communication

Received: 02 March 2021

Accepted: 15 October 2021

Published: 26 November 2021

Citation:

Carroll J and Bsumek P (2021) "All this Regulatory Uncertainty in the Air": The Indispensability of Public Hearings in

Guarding and Guiding

Public Deliberation.

Front. Commun. 6:675218.

doi: $10.3389 /$ fcomm.2021.675218

\section{"All this Regulatory Uncertainty in the Air": The Indispensability of Public Hearings in Guarding and Guiding Public Deliberation}

\author{
Jaclyn Carroll ${ }^{1}$ and Pete Bsumek ${ }^{2 *}$ \\ ${ }^{1}$ Sociology Department, Boston College, Chestnut Hill, MA, United States, ${ }^{2}$ Communication Studies Department, James \\ Madison University, Harrisonburg, VA, United States
}

The field of Environmental Communication has often critiqued the shortcomings of public hearings, noting their limitations in bringing about effective and equitable public decision making. While this work has been significant, it has tended to limit the deliberative field to public hearings themselves, sometimes going so far as to assume that public hearings are the only spaces in which significant deliberations occur. Using a field analysis of the "No Coal Plant" campaign in Surry County, Virginia (2008-2013), the authors illuminate some limitations of existing literature. Their analysis suggests that while public hearings can be extremely limiting, even "failed" public hearings can play a critical role in constituting, organizing, and pacing formal and informal deliberative spaces, which are necessary for communities as they manage the stresses and strains of the decision-making process.

Keywords: environmental decision making, public participation, public hearings, environmental communication, publicity

\section{INTRODUCTION}

Surry County, Virginia is a prototypical target for the development of LULUs, or "Locally Undesirable Land Uses." It is characteristic in its financial instability (both in the income level of residents and the financial instability of the municipality itself). Its infrastructure is deteriorating and in need of repair; its sidewalks are buckled, and its water system is failing. At the time of the Old Dominion Electric Cooperative's (ODEC) proposal for the production of a coal plant in 2009, Surry was on the tail end of an industry-provided grant that had been relieving some of these municipal burdens (or at least holding off infrastructural collapse). The county was also receiving national attention as the site of NFL star Michael Vick's infamous dog fighting ring. Surry was already home to the energy industry, namely a Dominion Energy nuclear plant on the James River. The county was a generally low-income and racially-divided community, with restricted organizing potential and community cohesion. It was not only embedded in the culture of "Coal Country," in Southern Virginia, but had direct ties to energy monopolies in the area because of other developments. It was predictable then that ODEC purchased land to construct the "Cypress Creek Power Station," a coalfired power plant in Surry County. Had it been built, the 1500-MW facility would have been the largest coal plant in the state. The project required a series of public hearings, at the town, county, and state levels. Theoretically, Surry's characteristics signal that any industrial development there would likely succeed with relative ease. It is unusual for communities like Surry to resist this kind of industrial development, but it appeared that this is exactly what happened. A resident's lawsuit set ODEC back in its local permitting fight, and a series of community actions delayed the project's 
development. In 2013, ODEC withdrew their permit applications, citing "all this regulatory uncertainty in the air," as their reason for withdrawal. The project has now been dead in the water for 8 years.

We sought out to position the case of Surry County within the literature on Environmental Communication and to interrogate how Surry experienced such unusual success. We found that the literature's existing characterizations of "deliberation," which center the limitations of public hearings in environmental decision making, eclipse most of Surry's actual deliberative field. We found that public participation in Surry was both reliant on and enabled by obligatory public hearings in unexpected ways.

\section{BACKGROUND}

Dendron (pop. 300) is a rural town in Surry County, Virginia located about 60 miles southeast of Richmond. At $1500 \mathrm{MW}$ and with $650 \mathrm{ft}$ smokestacks to tower stories over the tallest structures in town, the ODEC plant was expected to expose locals to coal ash, toxic waste, and harmful levels of mercury and heavy metals. Many in the community believed that ODEC's project was set to seal Surry's fate as a toxic community unsuitable for future agricultural or small business growth.

Surry County is like many counties in the rural south. It has, at times, relied heavily on agricultural subsidies and kickbacks from a large energy company. It is home to many empty storefronts. Families have lived in the area for hundreds of years, and as a result, for nearly every Black family in town there is a White family that shares its last name. Surry is haunted at every corner by Virginia's ghosts: slavery, racial violence, industrial dependence, agricultural monopoly, and municipal debt.

Surry's economy collapsed after farm subsidy rollbacks in the 70,80 , and 90s, and residents turned to logging, and soy and corn production. By the time ODEC arrived, the town of Dendron was rumored to be on the edge of disenfranchisement, and there were ongoing discussions about imparting Dendron's planning and zoning decisions to county boards. Communities like these are popular sites for LULUs because undesirable projects generally offer tax incentives and inducements that support underfunded municipal infrastructure and often come with an attractive but unfulfillable promise of employment opportunities.

By the early 2000s, LULU applications were rolling into Surry. A cell tower project launched in 2004, an independent contracting group proposed the development of a landfill in 2005 , and by the end of that year rumors about a coal plant were in the air. Some applications appeared to have been withdrawn in 2006 because of concerns about nearby wetlands, but in 2008, it was announced that the Old Dominion Electric Cooperative had narrowed their site search to Surry, and Sussex (a nearby county). From there, ODEC's path to construction would involve their acquisition of about 50 permits, 10 of which would have to be obtained locally. Most significantly, the land had to be rezoned from agricultural use to by-right industrial use and permitted for the construction of the particular project. Public hearings would be required before local permits could be obtained. By any expert's estimates, Surry was suited perfectly for a "quick and painless" public hearing and local permitting timeline. In fact, there is not much in existing literature on environmental decision making that explains why Surry did not become home to the Cypress Creek Power Station; but for 12 years Surry locals have held their ground and the lot remains empty. They achieved this largely by maintaining as much local control over the project's approval as possible, and by lengthening the public hearing processes as often as possible until regulatory circumstances shifted in their favor. It was a fight, in many ways, for deliberative time.An abridged timeline of relevant campaign events during the period can be found in Appendix A.

\section{LITERATURE REVIEW}

The study of environmental decision making and public participation processes is well established in the field of Environmental Communication. The aim of most of this scholarship has been to call attention to the inadequacies of existing processes and provide alternative models and frameworks. This work, which often emphasizes impassable barriers to representation (particularly for low-income and development-targeted communities) has framed decades of environmental decision-making analysis. In their review of this literature Hunt et al. (2019a) note that public participation processes, especially traditional structures and pathways, such as public hearings, are seen as "insufficiently open, transparent, or fair" (p. 5). They also conclude that the existing "laws, processes and institutions" associated with traditional public participation processes such as those mandated by the National Environmental Policy Act (NEPA) are conceived of in existing literature as "antiquated" and "no longer adequate to support robust public engagement” (p. 5). Specifically, the public hearings associated with traditional processes of public participation are critiqued as "perfunctory" and as techniques for legitimating decisions that have already been made. This has led to a tendency to dismiss traditional processes as forms of Decide, Announce, Defend (DAD) decision making where public voices are simply ignored or overlooked (Hunt et al., 2019a, p. 5; See also: Endres 2009, 2012; Hendry 2004; Kinsella 2004; Senecah, 2004; Walker 2004; Walker 2007; Johnson 2019). This attitude toward public hearings and traditional processes of decision making, such as those mandated and informed by NEPA, has shaped much of the scholarship in Environmental Communication on public hearings.

Much of this criticism can be said to be based on what Pezzullo and Cox (2018) identify as the "Politics of Voice" (p. 156). Scholarship in this area has called attention to the structures and processes of traditional forms and forums of environmental decision making as failing to provide participants with adequate and meaningful voice (Senecah, 2004), controlling voice (Buttny and Cohen 2007; Buttny 2015), and/or dismissing voice as indecorous (Cox 1999). Senecah's (2004) review and assessment of public hearings literature, perhaps more than any other scholarship, has shaped attitudes toward public hearing processes in the field 
of Environmental Communication. Her critique of public hearings is grounded in an analysis of the "theater style" proxemics "that are typical of local public hearings" (p. 28). In this analysis public hearings are a "weak form of public involvement" in decision making because neither dialogue nor debate is routinely produced in public hearings (p. 29).

Utilizing her oft referenced "Trinity of Voice" Senecah notes that while public hearings provide participants with limited access (opportunities to express choices and opinions), they rarely provide participants with sufficient and appropriate access, standing (civic legitimacy), or influence. Sufficient and appropriate access is limited by the decisions about where and when to hold public hearings, the extent to which participants have access to information, technical expertise, and the like. Similarly, standing, she argues, is limited by myriad factors including: "the placement of the public hearing at the end of the ... process, the time limit of the individual comments, the arrangement of the room, the reactions of the officials, the inaccessibility to the thick Draft Environmental Impact Statement (DEIS), [and] the lack of technical support to help citizens understand" complex issues and process rules (Senecah p. 31). All of these factors she notes, "reinforce the notion that citizens do not have much standing in the process, even if they have limited access to it" (p. 31).

Ultimately, Senecah (2004) concludes that without adequate access and standing those who attend public hearings have no meaningful influence. This is so because those without standing (civic legitimacy) are easily ignored, or they have been provided no "meaningful decision space." She further explains, that typically hearings lack transparency, do not provide opportunities for participants to "meaningfully scope alternatives," do not enable participants to "inform the decision criteria," and fail to provide "thoughtful responses to stakeholder concerns and ideas" (p. 25). In short, public hearings do not provide a space for stakeholders to engage in deliberative processes, such as dialogue and debate, with other stakeholders or decision makers, which in turn, deprives participants of meaningful voice.

There is ample research supporting Senecah's conclusion about public hearings. Transcript analyses of public hearings reveal that everything from the way that government agencies define the scope of the problem (Buttny and Cohen 2007; Buttny 2010; Buttny 2015, Koban 2019), to the way that scientific rationality and expertise are used to frame discourse and decisions (Kinsella 2004; Endres 2009) to dominant norms of decorum (Cox 1999) limit and constrain dissenting voices in public hearings. Further, even when this literature identifies the ways that participants in the public hearings attempt to resist these constraints, for example by using meta-discourse to reframe issues and address concerns about the processes itself, it is generally concluded that such efforts do not result in influence (Buttny 2010, 2015). Other research focused on public hearing transcripts starts with the assumption that public hearing processes provide participants with little influence over decisions, but concludes that analyses of participant comments are nonetheless meaningful because they provide insights into the perspectives, values, and rhetorical choices of participants (Mando 2016; Scarff 2021).

From our perspective much of the research on public hearings is limited by its focus on public hearing transcripts and its failure to account for the broader processes of environmental decision making. This is not a new claim. Pezzullo (2004, 2007) and Delicath (2004) have argued for expanding public participation scholarship to include analysis of activism, such as protests, rallies, art installations and toxic tours, all of which occur outside of official processes. Hunt et al. (2019b) have illustrated how "alternative, resistive, and transgressive rhetorical practices within public hearings, public information sessions, and other forms of sanctioned participation" have been overlooked because they are not captured in official transcripts (p. 153). Their use of rhetorical field methods enables them to show how "when used as a tactic, indecorum can demonstrate the radical potential of public participation processes" ( $p$ 157). In a similar vein, Cox (2010) demonstrates how the Sierra Club's "Beyond Coal Campaign" utilized official decision-making processes as a site for strategic intervention by mobilizing public comment in order to delay and derail the building of new coal-fired power plants as part of its broader campaign to end reliance on electric power generated by coal in the United States. Cox's description of the campaign and its strategy suggests that it is possible to exert influence through traditional decision-making processes, however, he does not describe how the campaign engaged with local communities to exert influence. Our discussion of the "No Coal Plant" campaign provides one example of how a local community utilized and relied upon official decision-making processes, especially obligatory public hearings, to do so.

Our case study explores the interplay between the outside and the inside of traditional decision-making processes. It starts by recognizing that the public hearing is but one part of the traditional obligatory environmental decision-making process - a process that involves a series of opportunities for scoping, comment, review of draft statements, and appeals in addition to formal public hearings. It also recognizes that in the case of large-scale projects, like the construction of a power plant, there are multiple permits that are required at local, state and federal levels, all of which require some form of official decision-making process. In addition, it recognizes that these decision-making processes often result in public controversies that are debated and discussed in the media and other public forums, both formal and informal. Further and most importantly, it accounts for the ways that local-residents and their allies engaged the interplay between the inside and the outside of these official processes. This case study addresses two questions:

- Can obligatory public hearings present opportunities beyond their limitations to LULU-vulnerable communities? Is there any value to the public hearing process in the absence of "trinity of voice" or in the absence of being "heard"? 
- What can a field-level analysis unveil about the effects of thickly bureaucratic decision-making processes on local communities?

\section{METHODS}

The first author identified Surry County as a valuable case study based on her time supporting the "No Coal Plant" campaign from 2009 to 2013. While Surry represented a prototypical "LULU" scenario, the events of the campaign appeared to be out of step with much of what Environmental Communication predicts regarding the limitations of obligatory public hearings. The authors employed a "rhetorical field methodology." Pezzulo and de Onís (2017) have explained that "rhetoric is being rethought in fundamentally ethnographic terms... through the practice of field methods" (p. 3). This is, they explain, part of an "ethical obligation to engage unfolding events prior to others creating or deleting public records" (p. 4). Their review of the discipline's use of field methodologies demonstrates that they can be effectively executed from any number of positions including, "witness, performer, fellow worker, note taker, consumer, protester, community member," and in any number of contexts, including "negotiations... local rallies and protests... tours... governmental and environmental agency proceedings... and citizen advisory boards" (p. 7). Ideally, the occupation of these positions and contexts ought to be deployed together. Middleton et al. (2011) explain: "Viewing rhetoric as a part of social practice... means that rhetoric is not constituted simply by texts or textual fragments, but through a combination of material contexts, social relationships, identities, consciousnesses, and (interrelated) rhetorical acts that produce meanings and that are co-constructed between rhetor, audience, and particular contexts" (p. 391). This can enable researchers to engage discourse "left out of traditional written records" (Middleton et al., 2011 citing Pezzullo 2003). Recollections from proceedings, meetings, and local rallies, archival analysis, media review, and indepth interviewing were all employed in our analysis of Surry's deliberative landscape.

Rhetorical field methods have great potential for analyzing "situations in which meanings depend on places, physical structures, spatial delineations, interactive bodies, and in-themoment choices" (Middleton et al. (2011), p. 388). In this case, the field methods approach provided an enriched understanding of Surry's deliberative landscape. In addition to contextualizing the relevant events, accounts, and archives, the first author's firsthand experiences in the community provided insight about where to look for information, whom to interview, and how to identify leadership. This has been identified as one potential benefit of rhetorical field methodologies. Middleton et al. explain, "rhetorical field methods avoid bracketing out insights that fail to gain the status of objectified texts." Pezzullo has noted in multiple essays that interviewing "humans in the know"... may offer opportunities to listen to voices too often left out of official archives and to identify rhetorical processes that exceed singular events (Pezzullo \& de Onís 2017, p. 9). In our case, several interviewees would not have been recognizable as relevant to an outside observer with only transcripts to rely on; though they were not "official" leadership these participants were highly involved stakeholders and key strategists and they provided irreplicable observations to our analysis. Middleton et al. explain, "By accessing... "live" elements of rhetoric suppressed in textual representation, and by focusing on communities often excluded from critical analysis (e.g., the mundane, the oppressed, the oppositional) rhetorical field methods both challenge who counts as a rhetorical community worth studying, and what counts as a form of rhetorical action worthy of scrutiny" (Middleton et al., 2011, p. 389).

The first author's experiences in the campaign were not catalogued at the time, but her years attending public hearings and community meetings, note-taking at events, speaking regularly with residents and professional organizers, building relationships, and babysitting for residents' children while they attended campaign events, served as a critical foundation for understanding the community and the events surrounding the "No Coal Plant" campaign. To enhance clarity, she reviewed videotaped interviews with residents from a documentary she filmed for the campaign in 2012. She also facilitated an additional seven in-depth interviews (ranging from 1 to $3 \mathrm{~h}$ in length) with participants at different levels of involvement with the campaign. This included professional regional organizers, professional national organizers, Surry residents, local politicians, and a student organizer. ${ }^{1}$ Interviews were further supplemented by a review of local news to solidify the timeline and clarify campaign details. The authors were also given a campaign playbook by an interviewee (a portfolio of notes, reflections, and news articles related to the campaign's events). This archive also provided helpful context. Interview transcripts were thematically coded for articulations of relevant events, for characterizations of stakeholders, and for characterizations of the deliberative process itself (both within and outside of formal hearings). All these analytical components were mobilized in our rhetorical field analysis of the deliberative landscape in Surry County, and enabled us to identify several gaps in Environmental Communication's representations of public deliberation, particularly with regard to the potential and limitations of required public hearings.

\section{FINDINGS}

In the case of Surry County, we did find evidence of stakeholders (particularly residents $)^{2}$ not feeling heard by their representatives

\footnotetext{
${ }^{1}$ These interviews were performed in accordance with and under the approval of Boston College's Office for Research Protections.

${ }^{2} \mathrm{We}$ use "stakeholders" to refer to all stake-holding actors in the campaign, including locals from the town of Dendron or Surry County, potentially impacted citizens of what they called "downwind communities" (nearby towns that would likely experience the effects of the plant indirectly) but who were still seen as "outsiders" by many locals, and professional organizers who lived in-state or represented regionally-specific environmental protection organizations but who did not necessarily live in local or downwind communities (generally seen as "outsiders" by locals, some seen more favorably than others).
} 
at public hearings. There was also a great deal of evidence, however, that stakeholders did not expect to have their voices heard. In fact, residents both named and planned strategically around the expectation that they would not be properly heard or represented in the public hearings. Still, public hearings remained a critical component of community deliberation and campaign strategy. Our analysis suggests that this may be due to local perceptions of the deliberative process; stakeholders in Surry tended to describe the deliberative process as unbound by the hearing events themselves, but they benefitted enormously from the obligatory structure of the requisite hearing process. We also saw some evidence that disjointed expectations about the deliberative scope of the campaign between locals and outside organizers introduced additional strain to an already burdensome experience for community members.

In this paper, we posit that Environmental Communication's attention to the limitations of public hearings may have overlooked the role of formal hearings in constituting informal deliberative spaces. Specifically, it has overlooked the role of the formal hearing timeline in clarifying and pace-setting informal deliberations. As a result, existing models tend to overlook the indispensability of even the most inadequate public hearings. Even these "failed" hearings, we found, gave structure to indispensable elements of the deliberative process and enabled the community's ability to defend itself against accelerated industrial development.

Our findings are based on four observations in the case of Surry County. First, and as the literature predicts, required public hearings were not a place where "No Coal Plant" stakeholders felt heard by local leaders, regulators, or ODEC. Second, however, many stakeholders did not expect to be heard in these hearings, and while the hearings did not deliver an equitable or effective deliberative space, they were repeatedly characterized as indispensable to campaign strategy. Third, the vast majority of deliberation around the Cypress Creek Power Station project was housed outside of public hearings, in informal spaces that we refer to as the "deliberative backstage." At times, this was illicit (e.g. on the part of ODEC), but more often, this was how the community used the public hearing timeline to guard other, more valuable deliberative spaces. Finally, we came across a great deal of evidence that this kind of deliberation places an enormous burden on small communities, often presenting real hardships in their daily lives and strain in the "deliberative backstage"; we suggest that this has been an overlooked element of Environmental Communication's reckoning with public decision making.

\section{Public Hearings and Not Being Heard}

Formal public hearings in Surry County were rarely "civil" and were reminiscent of many of the failures described in the field of Environmental Communication. Voices were often silenced (Cox 1999) or amplified (Hunt et al., 2019b) because of their "indecorousness," but most citizens were simply slogging through the strain and abruptness of a conflict of such complexity and magnitude. When we asked Lacey, a member of the Dendron town council, whether she felt the council was knowledgeable enough about permitting to navigate the hearing process, she laughed. "Oh God no! Not at all. They were getting information from ODEC. Pretty much all the town council did other than put out water bills was deciding when the potluck dinner for Christmas was gonna be, and who was going to be in charge of which food. It's not a bustling municipality by any stretch of the imagination." This is typical of LULU sites. Our interviewee Tom, the regional director of a national environmental advocacy group commented:

\begin{abstract}
"This is why a lot of these companies, whether it's a coal plant or a gas plant or a chemical plant, why they locate in rural areas. Because they know these areas are poor. The county itself is probably not particularly equipped to analyze what is being proposed. So, there's a conscious effort on the part of large projects to locate in rural areas where resistance can be weak, and scrutiny can be limited."
\end{abstract}

In addition to economic constraints, some towns can be susceptible because of their cultural attributes. In this case, the ethos of a small, southern town was significant. "I think it's more of the way folks are [in Surry]," offered town councilmember Lacey, "Like, you don't ask for too much because you're afraid it might go south or whatever. I don't know if they ever felt they should ask for more, even when they were told they could. The "I don't ask for handouts" kind of mentality is very prevalent in most of these communities." The public hearing process was (perhaps predictably) incredibly problematic.

Local stakeholders recounted many instances of outright systemic abuse that restricted access to public participation. And these stories were reminiscent of the public hearing failures described in other studies (Particularly Senecah 2004). Access was compromised, for example, when local officials attempted to create a veneer of "fairness." At one public hearing, anticipating that an overwhelming number of residents would speak against ODEC's permit, the council restructured the event to "level the playing field." Participants were asked to sign in at the door, to assign themselves to a column ("for" or "against") so that they could be called upon in alternating order "one for, one against" and so on, creating the appearance of local support for the project. Mandy, a Surry resident and campaign leader, remembered, "The newspapers were saying, "Well it was a fairly even count," because they would leave before it got the point at one o'clock in the morning where it was against, against, against, against, against." This is a more intensified version of what Patterson and Lee (2000) call the rhetoric of "balance," the treatment of "the public" as an interest group worthy of partial influence alongside other stakeholders, for example, industry representatives. In Surry, however, even the "interest group" veil was left off, and collective opinions were simply weighted and reorganized to produce the fraudulent appearance of balanced viewpoints within the public.

Town councilmember, Lacey recalled a more explicit attempt at illicit, backstage decision making: 
"[ODEC] had some informational thing. . . but it could only be for supporters of the project because nobody who had voiced displeasure was invited. And they invited the entire town council to that, and I remember calling [ODEC's attorney] and saying, 'I have some concerns about this meeting, this thing you guys want us to go to, because aren't you aware that when more than three of us are in a space it constitutes a quorum?"

As she remembered their awkward and oblivious response she laughed, "How the $\mathrm{f}^{*} \mathrm{ck}$ would you not know that? You are just counting on us to show up and do something nefarious!" Regional environmental organizer, Dan, also had suspicions that ODEC had been guiding the city leaders behind closed doors, providing legal counsel and lobbying them privately. "I think they had interactions with ODEC people and lawyers and they told them what they thought was the most strategic information." These stories are reminiscent of critical Environmental Communication research on public expertise.

At one of the public hearings attended by the first author in February of 2010, 150 people gathered in Dendron's firehouse for a significant local vote on land zoning. The vast majority of citizens stood in opposition to the plant, and tensions ran high. There was shouting and a great deal of "indecorous" conflict. A councilwoman threw her copy of the project application at ODEC's lawyer, the mayor seemed to warn a visiting environmental lawyer that he'd be jailed if he overstayed his public comment time. A split council voted to approve the application without including proffers to guarantee employment opportunities, municipal improvements, or independent environmental impact evaluations; and locals left looking some combination of outraged, exhausted, and unsurprised. Both the pace and the intensity of the hearings felt out of place in the otherwise serene landscape of Dendron.

Sometimes the system appeared more broken than explicitly manipulated. Locals were troubled by the early realization that their representatives were under no legal obligation to vote alongside expressed majority or expert opinions, even when it was clear that councilmembers did not have the expertise to fully understand what they were voting on. Regional Organizer, Dan recalled a comment made by the Mayor of Dendron. "I know that she didn't know anything about coal because months into this at a public hearing she asked if the coal was going to be made on site. They had an incredible ignorance to what they were getting themselves into, and I use that word, of course, really to say they just didn't know."

Looking at these stories alone, the Surry case appears to be a classic public participation failure that would lead to the project's easy approval by state and federal boards. A low-income community was explicitly and implicitly disenfranchised due to their limited access to expertise, the influence of industry, and the limitations of the public hearing model of public participation. It was a difficult pill to swallow for some residents, that public hearings do not necessitate, in any way, that the public would be heard. Surry was, quite clearly, set up to cave to industry pressure and to have their hand held by both industry representatives and environmental regulatory agencies as they signed their town over to coal in a series of puppet hearings. Armed only with literature that explains the limitations of participation, we may be led to assume that the hearings were entirely without value, that communities and advocates are unilaterally unable to transcend decision making constraints. But ODEC's project didn't succeed. So, what can be learned from their unlikely circumstance?

Some existing theories aren't entirely compatible with local deliberation at this scale. For example, local elected officials did not have the grounds to reject the "attitude or standing" (Senecah 2004) or "indecorous voices" (Cox 1999) of their constituents. These elected officials came from similar cultural and educational backgrounds as most of their citizens, and if anything, they were put off by "highbrow" input from those offering scientific or public policy expertise. "Decorum" and "standing" did not mark a barrier between elected officials and citizens at the local level. In another vein, (Cox Callister, 2013) warned against the dangers of detached land and culture logics in public deliberation, but Surry was never in danger of this either. In a county like Surry, culture and nature are held in one hand. A local farmer, worried about the pollution of his crop, would plead with a pro-coal neighbor, knowing she is in desperate need of work and that her sister's salary as a teacher is subsidized by a coal-industry grant. Land and industry are, in many ways, the backbone of Surry County, and the primary logics with which residents approached ODEC's proposals.

Locals also appeared to adapt very quickly to an understanding that they would not be heard at public hearings; in many ways they were not burdened by this expectation for long, they simply re-directed their efforts accordingly: "We knew very, very early on that that our public comments were not going to move board or council members," recalled Surry resident, Mandy. "We knew that decisions had been made, before that ever even started, so our point, again, was to draw out this process, but also to shame the hell out of them." Importantly, this strategy relied on the promise of public hearings. The hearings were quickly understood by residents and activists as a point of leverage rather than an endgame. Hearings were simply where they could achieve and protect the necessary time and space for community deliberation.

In our interviews, and in the first author's experience of the Surry campaign, public hearings were not understood as the primary decision-making site by professional organizers or locals. Interviewees had incredibly low expectations about the efficacy of the public hearings. The most optimistic hoped that town and county officials might be swayable about land rezoning or attaching proffers to the application; the least optimistic assumed unilaterally that people's voices were not, and would never be, heard. Surry resident, Mandy recalled a town hearing, where she and her husband had to explain these expectations to a local journalist. At the end of the hearing's public comment period, hours of public questions and comments, the council read a statement which had clearly been written and printed prior to the hearing. Mandy explained that the journalist in front of her was confused by this, "[She]turned around and looked at [my husband], (and she knew who we were)... She looked at [him] 
and she said, "They've already got the motions written!" And [my husband] was like, "Yeah, you think? This is already done!" And there was a moment when her face like changed, and I was like... We have been saying for years that the fix is in... this isn't about listening to people."

But these hearings were incredibly well-attended by those opposing the project. Hard-working people left their kids at home on weeknights and waited hours and hours for their time at the microphone. There were nights when hearings went until 1 or 2 o'clock in the morning; there were evenings where the weather was so bad, and the firehouse lawn was so full that people arrived home stained up to their waists from pushing cars out of the mud. Even without the hope of being heard, there was a strong drive to continue participating.

\section{The Indispensability of Inadequate Hearings}

To understand how these hearings could possibly have had value to stakeholders in spite of their serious limitations, we ought to revisit how exactly the campaign succeeded. The "No Coal Plant" fight was slated to be litigated on three stages. First, at the local level (town and county) decisions about land use and zoning would be negotiated. Second, at the State level ODEC would have to acquire a series of air and water quality permits. And third, ODEC would have to adhere to Federal guidelines. For ODEC, the journey from land acquisition to plant construction would be segmented by a complex matrix of hearings, votes, and evaluations, in which any hiccup could become very costly very quickly. ODEC was perhaps more vulnerable to these interruptions than other energy corporations for two reasons: ODEC is a much smaller and less influential player than other coal titans in the region, and ODEC is a "cooperative" where energy buyers have some ownership over the organization's actions. There would therefore be less room for (and less tolerance for) mistakes on ODEC's part. Local stakeholders were well aware of this. The campaign also took place during President Obama's administration, so in the background of the campaign there were rumors of soon-to-be-shifting EPA guidelines which would intensify regulations on newly built coal plants. These proposed new guidelines were ultimately publicized in early 2012, the year that ODEC had originally projected the completion of construction, but ultimately before ODEC was able to begin construction due to delays. In addition to these three stages of approval, a fourth stage was introduced after the Dendron Town Council failed to appropriately notify the public about a local zoning vote, resulting in a lawsuit which sent ODEC back to the very beginning of the local planning and zoning process.

What this timeline indicates is that local resistance efforts bought the campaign critical time as restrictions were tightening at the federal level and as locals "got their arms around" the issues at play. Locals began working early on to keep the town council from ceding control of planning and zoning to county boards, and organized to protect hearings and slow the town council from rushing to a decision. They organized events and worked to get the word out. They made lawn signs and built a small cohort of allies. They performed immeasurable hours of research, and worked hard to connect with other community members, forging relationships and educating each other. When ODEC pushed the town council to rush through one of the early zoning votes, residents sued, forcing ODEC to re-litigate these illicit hearings years later. Locals attended even the least interesting permitting events and hearings, making their presence and their distaste for the process known as often as possible. And they made it impossible for ODEC to accelerate the process. They made it impossible for ODEC's actions to be invisible to locals.

All of those interviewed agreed that required public hearings were a deeply flawed deliberation format, but crucial nonetheless. Regional organizer, Tom thought,

"I don't disagree that the hearings are sometimes not decisive with regard to outcomes, but they are an opportunity for the grassroots to show their power, okay? I mean we're not going to be able to buy our way into the little private soirees that ODEC might have or Dominion might have with the governor or with the $\mathrm{DEQ}$. They are an opportunity for us to turn out large numbers of people and for them to show their concern and in some cases even their contempt for the process. This reinforces the good technical information that we have but also demonstrates the will of the people."

This was in line with the "Beyond Coal" strategy articulated by Cox (2010), a campaign which several of the professional organizers in Surry had ties to. Another organizer echoed these thoughts: "We kept showing up and banging the drum like maybe they'll listen, you know? I think [the public hearings] are still practically valuable but now I think that's because they're openings for attacking and shaming politicians, using that to bring the media in, stuff like that."

In many ways, the goal of the campaign was to keep the issue active with the press and the community, to extend the time and expand the space for much needed discussion and deliberation. Chase, a regional organizer and environmental lawyer, remarked, "We hoped that a robust discussion would help, that if we could keep the debate alive, robust discussion would help turn some votes our way in the public policy debate but it wasn't like, 'We should debate this until something else magically happens." Chase's hedged remark points to a hesitation expressed by all of the professional organizers interviewed. They were hesitant to use the word "delay," or suggest that they were engaged in "delay" tactics. While locals and those closest to the campaign were comfortable saying, yes, we were striving to delay the process, outsider activists were quick to reframe. "That wasn't the first thing on our campaign, to cause a delay, that wasn't our message... I don't think it would have been perceived as well if we were just trying to delay it. .." Chase was less direct: "I don't think there was ever a sense of, "We need to kill time or delay this until something else happens," I mean I think that was a criticism from the other side, but that was never in any discussion I had with folks what people were thinking that I can recall."

Those closer to the strategic center of the campaign were a bit more comfortable with the idea of "delay." Surry resident, Mandy was very forthcoming, "The longer that we delayed it the more people knew about it... and the more people were against it, you 
know?" Regional organizer, Lauren (an outsider, but at the strategic center of the campaign) was on the same page. "The underlying strategy was we wanted to delay. As long as we could delay everything, it would become too expensive, and people would just start bailing. And every time that a study was pushed back and we had time or a hearing was pushed back or a hearing was added, we had heard from many other campaigns that this was the name of the game for victory... That's how you do it." These accounts speak to the value of delay as something more than bureaucratic friction or the needless burdening of development. They understood delay as the preservation of much-needed but unawarded deliberative time.

Targeted communities are given scarce time to orient to environmental decision making, and without an ability to delay efforts, "Decide, Announce, Defend" is all many municipalities can hope for. Many decisions made at this level require only two-weeks-notice for a vote or public hearing. Community members are only involved sooner if they have the benefit of being connected to "the talk of the town," or if local representatives feel compelled to speak openly about possible emerging developments. Is there any possibility that a community of people, many of whom work more than $40 \mathrm{~h}$ a week with the added burden of a ferry-ride commute, could prepare themselves for a decision of this magnitude when the required public notice for a vote is in 14 days?

Surry resident, Mandy pointed out: "It's just one of those things where like you don't even know what you don't know... I didn't know what a FOIA request was. I didn't know what a planning commission did. I didn't know what appeals board was. I didn't know what an air board was. I didn't know any of that." Local residents like Mandy were careful to point out that the process is not entirely out of reach, but it is out of reach when it is deliberately accelerated. The ability to self-educate was always there, not for every resident, but for enough residents to build a leadership core. In Surry, it was a group of homeschooling moms who developed a small community together. Mandy went on:

"People can figure this sh^t out. It's not rocket science. Local code is not rocket science. FOIA requests are not rocket science. This sort of thing is not that complicated. It's just that most people aren't involved in it, you know? It's like when they hand you the baby at the hospital and you're like "ohhhh my godddd what? I've never done a diaper befo- wha- what???. ." We're all fully capable of coming into these situations with a learning curve that looks like a straight up cliff in front of us and like scaling it. It's really not that complicated, like yeah your government isn't maybe creating dog-like mutants that are gonna come and eat your children, but also they're probably fudging some of the local ordinances, or the freedom of information act stuff and you can fully catch them in that, and that is your friend..."

Indeed, the idea that deliberation takes time is nothing new. Scholars of deliberative rhetoric have long noted that it is axiomatic that deliberation requires time (Hart and Dillard 2001). And in Surry, having that time allowed participants to build a more authentic community discourse. Regional organizer, Lauren explained that there was an emotional burden relieved as well:

"I think there were times where the locals became overwhelmed and then it sometimes became destructive because they were... they were so emotional, but rightly so! People were taking a lot of time and really jumping out of their comfort zones, whether that was door-to-door canvasing or listening to a person that they otherwise maybe would never be in the same room with. And I think it really took a lot of people to open up to kind of start those relationships and work through a lot of those pains."

She went on, “... There's no question that once you put a sign in front of your yard, it really does generate momentum. It starts a conversation with your neighbor, at your local market, and then people were identified, and people were reaching out wanting the signs. And we knew who we could bring into the fold to help, you know, arm them with information about coal plants or about the approval process, and then we saw, you saw, local leaders step up. And once those local leaders stepped up and took charge, it was. .. and that's the way you want a campaign to work, I think that's the ideal way."

For Lauren, time allowed local leaders to emerge, and reduced the need for locals to rely on the control of outside experts. Time to familiarize themselves with public process, time to begin conversations with unlikely neighbors, time to unpack the emotional burden of managing this threat, time for leaders to gain comfortability in that role-these were just some of the relational processes that Surry required, and that relied on delay. Communities are not, generally pre-organized for the kind of advocacy work that is required to participate in these kinds of decision-making processes. This requires "predeliberative" work.

During "bought time" as stakeholders engaged in required meeting and hearings, local stakeholders also forged strong and unconventional allyships (within the community and with outside organizers), producing and enriching deliberative spaces outside of these formal contexts. Surry, like most communities, did not arrive "deliberation-ready." Relationships needed to be solidified. Locals needed to learn the ins and outs of land use, zoning law, DEQ regulations, and more. And locals needed to strengthen connections with external organizers and experts (which were, in many cases, burdened by cultural difference).

Stakeholders suggested that while public hearings were not a place they felt heard by officials, they were a place where they felt heard by other community members. The hearings were a crucial pathway for accessing, leveraging, and contextualizing other deliberative sites. Regional organizer, Lauren offered:

“... Those larger hearings when you stand up and you talk to the Air Board, those big hearings? Yeah, those 
were just bullsh ${ }^{\star}$. . . was it a total waste of time? No, I think, you know I think that it was good... The only thing those hearings did was show that we had numbers. And it connected us to other people who did not know that we exist. So whenever we went to those hearings, we knew who our people were, and then if we didn't know, and you spoke out against the plant, we put you in the fold. And then of course hearing people support the plant and why they supported the plant and then further tweaking our messaging so we could address things like job creation and the economy and how that could be easily broken apart because, you know, their numbers were insanely distorted."

State hearings, Lauren recalled, didn't live up to their stated purpose, but they were still imperative for community deliberation. They allowed for people to become acquainted with each other's values, concerns, and hold-ups, and for people to connect with allies they had not met.

These "failed" hearings also became a mechanism for pacing and constituting informal deliberative spaces elsewhere. Strategy potlucks were held in living rooms and coffee houses (usually in preparation for an upcoming hearing), and at these potlucks homeschooling moms, local democrats and republicans, park rangers, plumbers, environmental lawyers, farmers, and students gathered to eat and work. Hardcore Tea Partyers with American flag suspenders and punk-rock-looking student activists discussed their lives and complimented one another's casseroles. These spaces were critical in helping strange bedfellows forge trust and integrate "expert" strategic advice with local knowledge. They were also a place for locals to truly deliberate, integrate new information, and express uncertainty about the more abstract issues at play (like environmental regulation or climate change), which was surely not available in public meetings.

While the hearings themselves often felt fruitless, they provided a reason for potlucks to be held and provided an agenda for stakeholders to confront. Divergent expectations could be streamlined and organized to some degree by the way obligatory hearings segmented and paced the many components of the campaign. One week could just target air quality permits. Another might focus on planning and zoning. Another might focus on the possibility of proffers related to employment opportunities and scholarships. It was in these spaces that locals strategized to request delays and postpone votes with local councils, for the community to consider alternatives and acquire further research. When necessary, professional organizers could explain elements of the hearings or the regulatory process. And when called for, locals could provide context and re-direct. Locals could focus their efforts (and manage conflict around) smaller components one at a time. Heated debates about hot topics could be tempered and reorganized. While these meetings were in no way a deliberative utopia, relationships were solidified, respect was garnered, and unexpected shared ground was often reached.

\section{Managing Deliberative Space and The Deliberative Backstage}

While all stakeholders seemed to see the public hearings as strategic opportunities rather than the whole of the deliberative environment, there was still some disagreement about how to orient to them due to disagreements about the appropriate deliberative scope of the campaign. This was a source of conflict for some and required finessing for the preservation of campaign cohesion. Professional stakeholders often saw the local hearings as the prequel to state hearings, a space where grounds for lawsuits could be identified and where a case could be built for delaying the project. Also in the air was the sense that changing federal regulations under the Obama administration might make the project less attractive if delays could push the project closer to these changes. They were therefore often more focused on gearing up for litigation down the road or "cleaning up" locals' messaging to focus on litigable facts. Regional organizer, Tom, who represented a "Big Green" environmental organization, reflected:
"I've seen situations where there was something that was not popular with the local folks but from the standpoint of winning was more strategic. . Okay, so you can say you don't want it, but the DEQ doesn't work that way, you know? That's not the way they work, so you need to make legal arguments that are sometimes maybe not necessarily popular with the local folks, but there's strategic stuff involved."

His understanding of the scope of the deliberative landscape, however, was different than that of many locals, who believed that the project could be halted at the county-level, without involving statewide agencies (and by extension, without involving more abstract political debates about environmentalism and climate change, which many locals had no desire to engage). As such, locals prioritized the deliberative landscape surrounding local votes and the mobilization of locals in their opposition of this project. They hoped to end the fight on the county level where they had more control and a stronger hold on the media; they prioritized drumming up local resistance and press over preparing for litigation. Budgeting energy for a state battle seemed like a forfeiture of home turf, and these two arenas required different messaging. Town Councilmember, Lacey reflected:

"I think the biggest thing that sort of got me with the larger environmental groups was. . . their talking points weren't stuff that were going to work. Like you couldn't have gone in and talked to the Surry County farmers about climate change, the vast majority of them being Republicans and they were Tea Party Republicans from the south."

For Lacey, it simply wasn't strategic to allow the deliberative landscape to become statewide so quickly, as it introduced 
polarizing language that might have disoriented locals who were averse to "environmentalism" but also averse to industrial development in their community, and who would not have had sufficient time to research and process the more abstract elements of the conflict. Surry resident, Mandy spoke even more directly about the clash of expectations:

"The environmental groups have a long history of fighting these fights, and they don't deviate much from a playbook that the utility now knows. So, the utility [the coal company] came in very early on and they were like, "Ok, [the environmentalists] are gonna come in, and they're gonna say this, and they're gonna say that, and they're gonna say this." And then the environmentalists came in and they said all of those things, and guess what? That built up the credibility of the utility among the local people!. . . They were like "Oh my god that's exactly what they said! Polar bears! How did you know that? Oh my god you're so smart you know everything."

She continued,

“... This is the thing that drove me so crazy about the professional organizers is that they didn't seem to care about any of this local zoning stuff. Like, sort of, they were interested and they were like, "Ok yeah, we should go and we'll send out an email and whatever." But we kept looking for ways to really stop it in this beginning stage, you know? We had these four opportunities to go in and create havoc and shut this thing down and, you know, they kept saying, "Well, we'll wait until it gets to the state level." Well, you know, if you're not throwing it all in now, I don't know what you're going to do at the state level... [Laughing] I mean, we were hoping that anyone was listening, honestly, and this was another handful of spaghetti thrown at the wall. We were hoping that locals would see this and find it, no matter where they stood on the issue, that they would understand that this was wrong, and they did, they didn't like it. People locally did not like it. We were hoping that the reporters would describe the meetings as being like, "Despite overwhelming public opposition, Surry voted for this." We just wanted that truth to come out... That this was a sham."

Mandy saw environmentalist argumentation as the third rail of local deliberation and hoped to protect locals from federal political debate and outsider language. In this sense, both the organizers and the locals were attempting to modify and modulate the deliberative scale of the campaign in order to reach different goals. While these conflicts are of great consequence to community organizers, who would be better equipped for these campaigns with an understanding of the complexities of the deliberative landscape, they are also of theoretical importance. Decision-making frameworks that limit our scope to what goes on in public meetings can overlook the active management of deliberative scope by different stakeholders, and the conflicts that can result from these efforts. Furthermore, they can obscure that these necessary informal deliberations are complex, entrenched, and fundamentally unsolvable in the "14-day advance notification" of public hearings.

These episodes can be understood as the "deliberative backstage" of environmental decision making. Backstage discourse is critical to a community's deliberative process, but exists outside of formal deliberative spaces and is not typically captured in hearing transcripts or news archives. It is in the "deliberative backstage" that disconnected or unacquainted locals forge relationships, network, and build trust. It is where cultural differences and strategic expectations are mitigated between residents and outsider-allies. It is where stakeholders negotiate the most strategic approach to formal spaces like public hearings, and it is where "the professional playbook" has to reckon with local values and local culture.

\section{The Burden of Deliberation on Small Communities}

It is also in the deliberative backstage where the burden of deliberation on small communities is most visible. One of the most alarming observations made by participants, was with regard to the stronghold of "Big Coal" actors on the community, even though the project developers in this case were a competitor of Virginia's largest energy monopolies. Participants spoke specifically about the influence of Dominion Energy on local deliberation (even though the Cypress Creek Power Station was being developed by the Old Dominion Electric Cooperative, an unrelated energy co-op). Michael, a student organizer who worked for several years on the campaign, recalled ways that industry interests were drawn into the local field. There was an understanding that regulatory agencies and industry representatives had "an interest in making sure Virginia was a place where a coal plant could get approved regardless of local politics." Surry resident, Mandy expanded, speaking more specifically about the influence of Dominion Energy:

"The county is like, "Well we don't wanna piss off Dominion, so..." [Once, when a solar company] offered to do an entire energy audit for our government center and they turned it down, and our county administrator told me himself, "We have to be very careful how we come across to Dominion, we cannot step on anyone's toes here."

She went on to explain that the community already relies on Dominion Energy for a grant that generously supports the local school system, and by extension, provides employment security to many locals:

"So you get a job at the school. You're an assistant to the assistant to the assistant. . this is a way that people are 
taken care of here... People were all like "Well they probably just pay them off." And I was like. . . they don't have to pay anyone off! This is this community. This is this culture. They have gone to school with these people since they were 5 years old, their uncle works there, their aunt has a severance package from there, like you don't understand how it works in a small community... you're not gonna bust up in there for one weekend and like fix it. . . they don't need anyone to give them any bribes to make it be that way, that's not [laughing] that's not how it works."

The impact of Dominion Energy on local perceptions of the need to be deferential even to Dominion Energy's competitors speaks both to the significance of the deliberative backstage and the alarming cultural influence of the coal industry on the region.

Even without the influence of industry, the burden of the deliberative process on small communities is almost unimaginable. These cases involve a collision of local, statewide and federal discourses about industry and the environment; and this can be incredibly overwhelming for a small municipality. While these challenges were finessed rather well in Surry, this finessing required a great deal of additional deliberative time and space. Respect and trust were mitigated by people's interpersonal contact with other actors. Trust was built between locals and outsiders when outsider-allies or professional organizers stayed past their "on-the-clock hours," missed convenient ferries out of town to keep debriefing late at night or took the time to get to know locals' children. Distrust, on the other hand, intensified when outsiders violated cultural norms (by overlooking etiquette, forgetting names, or interrupting community leaders at meetings), when professional organizers urged locals to operate at an unfamiliar pace (by calling late at night or expecting locals to step out of their lives entirely to prepare) or, in a somewhat infamous episode, when an outsider brought a box of gas station donuts to a community potluck.

The intensification of racism within the community was a huge issue as well. It appeared to many White locals that there was a concerted effort early on by ODEC to reach out to Black religious leaders in town about the economic benefits of the plant (though promises of employment opportunities and other benefits were never formally ensured). This posed an enormous threat to community cohesion. During her years working in Surry, the first author rarely saw collaboration across racial lines and she rarely encountered Black community members at anti-coal plant events. In fact, there was often an absence of Black voices at public hearings, but there were whispers of another backstage when they did. At one local hearing, a Black woman stood up in the audience and with her back against the wall announced, "I'd like to go on record as saying tonight to the person who keeps threatening me, I still mean the same thing"... At this point, she held up her "No Coal Plant" sign and said aloud, "No coal." And walked out of the meeting. Surry resident, Mandy once described a Black leader in the community, a town councilman who was found vomiting outside a public hearing after a stressful vote. She recalled him saying to her, "I have to do this. I have to. There is so much pressure."

The first author's inability to engage with any Black community members is a limitation of this study. And the racialized burden of environmental deliberation on small communities should be further interrogated in future research. But it was clear even from a distance that the deliberative process had a particularly stressful effect on many Black residents in Surry, and that the deliberative burden was not equally distributed between racial groups.

White locals experienced extreme social stress in their "regular lives" due to the campaign as well, though these stresses appeared characteristically different. Surry resident, Mandy described:

"There's a party line. And if you do not toe the party line there are repercussions and primarily the repercussion in a small community is that you're ostracized. So people don't talk to you at church, people don't talk to you at the grocery store, or the post office. Your business no longer gets calls from people and, and we experienced this first hand... So there's a very heavy social price that you pay to speak out against whatever your community..."

She continued:

"We have a small business here. The county stopped calling [my husband] for his plumbing services, I mean they call an out-of-county plumber to come from Smithfield. We literally live across the street from the government center and they were like, "nope, you're out." And this is sort of how it works. . . So um, people's livelihoods are impacted.... And when you live the level of, you know, vitriol. .. I mean it was like, people were screaming at my children, like my neighbor was driving by and screaming at my children who were little, you get scared."

Town councilmember, Lacey recalled community efforts to get a local blueberry farmer, involved in the fight:

"You know, getting [him] interested in going to those meetings at the very beginning was like pulling teeth, but once, and I'm not kidding, he did not want to go, he did not want to have anything to do with it and it really wasn't until after we had like news reports about it. .."

While this farmer's involvement may seem insignificant, organizers later learned that Surry's premier blueberry farmer also had a law degree. He later sued ODEC for having improperly advertised a local vote, slowing down ODEC's application process, and ultimately requiring ODEC to re-litigate a key local hearing. It was around this time that ODEC lost momentum, and stopped pursuing the permits. But every player's commitment to the campaign came at a cost, and this strained and slowed recruitment to the cause. 


\section{DISCUSSION AND IMPLICATIONS}

These findings offer valuable developments to theorizations of "voice" in environmental decision making, building especially on Senecah's theorization of the "Trinity of Voice" and contributing to the work of Hunt et al. (2019b) on the public participatory process.

Our analysis of Surry County suggests that the deliberative field of environmental decision making can stretch far beyond formal public hearings, bleeding into both informal deliberative spaces and sometimes invading stakeholder's intimate lives, placing extraordinary burdens on locals. We found also that when the deliberative field is considered in its entirety, we can observe the incredible value of an obligatory public hearing process, even in situations where the prospect of a community having their voices "heard" is unlikely. In the case of Surry County, the hearings enabled stakeholders to maintain their right to deliberative time and deliberative space (even when this space was held elsewhere, in the media, or in other community "backstage" spaces). The obligatory hearing process also helped constitute, organize and pace informal deliberative spaces, helping locals learn, network, and build trust in a segmented timeline, which they had some control over speeding up or slowing down.

While future work on this subject should surely continue to criticize the limitations of the public hearing process (many of which we observed in Surry), it should do so with an eye on the position of hearings within a larger deliberative field. Without considering how these obligatory hearings constitute, organize, and pace critical deliberative processes elsewhere, we cannot make accurate recommendations about how best to address concerns, and we are at risk for eliminating valuable tools and further disenfranchising vulnerable populations. Already in the water are some troubling attempts at "re-designing" public hearing processes to make them more "civil" or "efficient." These are of incredible concern, given our findings. Regional organizer Tom, who represented a national organization, described his assessment of a concerning national trend:

"There have been attempts to modify [public hearings] to make them less effective. One thing that's been done is to rather than have a hearing where people stand up and testify, they have these tables and everybody has to go around to individual tables and talk one on one with a staff person who writes down your comments. That's something that's been done in a lot of places... sometimes they try a divide and conquer strategy where rather than letting people stand up and speak, and of course that process if very dynamic. It feeds on itself, people clap, people boom, people stomp their feet and its sort of a. . . a theatrical. . . and I don't mean that in a negative way, a means to convey mass public opinion, so many agencies have tried to diffuse that process by making the public comment period less of a public hearing. Another thing that's done with public hearings now with government agencies, is rather than having them at a public location, they have them at a hotel, and so because they have it on private property, we can't demonstrate outside the public hearing."

What Tom has highlighted is a concerning trend that disaggregates public hearings, and disables them as space-holders and pace-keepers by limiting all of the benefits we observed in the Surry County case, which rely on the ability to identify, hear and interpret the comments of other members of the public. Efforts like this should be seen as extremely dangerous to those guarding stakeholder voices in deliberative spaces. It is also worth noting that Senecah (2004) along with most other Environmental Communication scholars who champion alternative modes of decision making, such as collaborative and/or consensus-based models, point out that these modes of decision making are not appropriate for all circumstances and are best utilized only when there is collaborative potential (see for example Daniels and Walker 2001; Peterson et al., 2005; Clarke and Peterson 2016).

We sought out to address whether the obligatory hearings in Surry presented opportunities beyond their limitations, to consider whether there was any value to the public hearing process in the absence of any hope of being "heard." What we learned, was that by playing a role in constituting, organizing, and pacing informal deliberation, even failed public hearings were critical in the protection of stakeholders' deliberative time and deliberative space. We also found that the protection of informal deliberation was not only needed for the material issues at play, but also for managing inevitable social and intercultural conflicts and navigating the extreme emotional burden of the deliberative process.

The promise of public space is crucial for environmental decision making. As we indicated earlier the "No Coal Plant" campaign relied heavily on the publicness of the public hearings themselves. As Hunt et al. (2019b) argue public participatory processes should not be dismissed as co-opted spaces of DAD decision making precisely because they are also "important moments of radical rhetorical engagement and consequence" (p. 150). Public hearings, in particular, precisely because of their proxemics, not in spite of them as Senecah (2004) argues, create a forum that calls a public into being and enables participants to address that public. According to town councilmember Lacey, this constitution of publicity was essential to local resident involvement in the decision process.

\footnotetext{
"First of all, getting people out to meetings, again knowing that, you know, it was probably going to be off and on, you know, people were at least reassured that day, you know, I don't think any of us ever said, "yeah I'll be able to stop it," but I think they were at least reassured that there they were going to be able to speak, you know, and have their voice on record. .. even when, you know, we knew it wasn't going to change people's opinions... so I think that was really effective you know especially when it came to getting some of the key players involved."
}

Public spaces, spaces where people can come to together to address not only decision makers but also each other and wider 
audiences through media, are critical to environmental decisionmaking processes. In regional organizer and environmental lawyer, Chase's description of the well-known limitations of NEPA, he specifically highlighted its value in publicizing the process:

"NEPA is often criticized, saying "this is just a procedural statute,"... all it does is impose a "truthful teenager rule." So long as agencies tell the whole story and sort of... put all the information out there, they can still do the bad thing. As long as they just tell their "parents" what they're doing, the truthful teenager gets off without getting grounded. I think part of what that myth is and why I think it's still a valuable tool for advocates is it does inherently provide a lot of sunlight to the process. . . As the project stays in the public light and more attention is drawn to it through review of an environmental impact statement, the views of political actors on the ground might change, they might see what's going on and say, "You know what, we supported this earlier but now we don't."

Delay gets a bad reputation, but delay is only a bureaucratic drag to someone who does not realize the enormity of information a person has to accumulate to mindfully engage a decision like the Surry coal plant. Surry resident, Mandy's remarks are relevant here. Public deliberation guidelines "aren't rocket science," but the learning curve is steep and requires both logistical and relational adjustment. We believe that there are two ways that a focus on time can improve our scholarship on environmental decision making. First, we should recognize that adequate time is required for meaningful public participation in decision-making processes. Time is needed for community members to educate themselves about the processes and procedures of decision making, to manage the influx of outsider opinions, and for adequate deliberation. Meaningful public participation, or voice, may as Senecah (2004) argues, require access, standing, and influence, but adequate time for deliberation is also essential for voice in decisionmaking processes.

Second, and perhaps more importantly, scholarship on environmental decision making has tended to focus on particular decision-making events, such as hearings. We would do well to remember that legally required decision-making processes involve a series of events, each of which is but a part of the process. As such scholarship might focus on the whole of the permitting and/or NEPA timeline, not on particular decision points or public hearings within that larger process. In the Surry case, local activists and to some extent their allies understood this, which enabled them to engage even the hearings they understood to be "shams" productively and with purpose.

Surry activists were especially adept at making the distinction between deliberative-time and decision space. They understood that while many of the hearings they attended provided no actual decision space for them because "the decision had already been made," this did not mean that the hearings were not important vis-àvis public deliberation. The hearings provided opportunities for organizing their community, for accessing media and articulating their message, for identifying supporters and allies, and for critiquing the process and shaming political leaders. Even the names of the hearings helped organize the research process for those who may not have known where to begin, by allowing locals to focus on one targeted area of research at a time (land use, air permits, wetlands restrictions, etc). As Surry resident, Mandy's comments remind us, there is no playbook, no "what to do when a coal company moves to your community" button. But residents could look up terms like "air board hearing" or "wetlands permit" or "environmental impact statement" and make some headway. All of this enabled them to expand the realm of decision making beyond the space of public hearings in order to generate public attention. This was crucial to their "problem community" strategy and their ability to generate "regulatory uncertainty." More importantly, it forced decision makers to justify decisions in public view.

Another way that our analysis suggests that the spaces of environmental decision making should be expanded beyond the actual site of the public hearing relates to the implications and impacts of deliberation on communities. Our analysis of the Surry case highlights two ways this is important. First, local residents who became involved in the resistance campaign faced additional barriers to public participation in the decision-making process. Threats, intimidation and ostracism meant that local activists had to deal with social and physical vulnerability. In this way the space of decision making was expanded beyond the official sites of engagement and spilled out into the work-day spaces of the community. How community members negotiate these kinds of risks is important to understanding public participation processes. It is also an undertheorized aspect of decision making in existing scholarship.

Second, local activists had to navigate and negotiate relationships with outside forces including their own allies. Our case study calls attention to the tensions that were experienced when these networked publics endeavored to work together. It suggests that the process of creating networked publics is neither smooth nor uncomplicated. Rather it requires, sometimes fraught, negotiation and navigation. Future analysis of the ways that local activists and their allies make sense of this process can further our understanding of both decision-making processes and the ways that networked publics function vis-à-vis environmental decisionmaking processes (Asen 2017). Additionally, established advocacy organizations can and should pay more attention to the way that they engage with and support local activist communities. The deliberative field in Surry was an expansive discursive ecology, in no way confined to formal hearings and meetings. Deliberation bled out of these formal settings into grocery checkouts, school pickup, and church dinners. There were many deliberative backstages, and each of them was differently accessible to locals, their allies, representatives, "outsiders," and industry actors.

So how can we re-conceptualize the efficacy of public hearings? We first must introduce a framework that foregrounds their inadequacies and the injustices they enable, without dismissing or devaluing the important role they play in the process. By positioning public hearings as a part of the deliberative landscape, and by foregrounding "adequate time" as essential for public participation alongside Senecah's "trinity of voice," we achieve a more accurate framework for making sense of how and where community decisions are negotiated. Further, and perhaps 
more importantly, we recognize the imperative value of protecting public hearing requirements, despite their limitations. This is an imperative made all the more important by the recent reforms to the National Environmental Policy Act initiated by the Trump administration. The goal of these reforms was essentially to ease and accelerate the bureaucratic process surrounding industrial development (Buccino 2020; Hahn 2020). Our findings suggest that preserving and strengthening these processes is critical in ensuring that the public participatory process is equitable and effective.

These findings also call attention to the value of rhetorical field methodologies in the study of environmental deliberation. Pezzullo \& de Onís (2017) identified three areas that rhetorical field methods can clarify: culture, interconnection, and voice. Our case study benefited on all three fronts. Pezzullo's and de Onís' work allowed us to do more than simply contextualize archives. Field methods helped us more effectively define the parameters of communication itself in Surry, by observing what spaces counted as deliberative and what actions counted as deliberation among locals. This allowed us to observe a number of intracampaign deliberative conflicts which occurred outside of hearings. It also allowed us to understand locals' persistent participation in the hearing process, despite their continued expressions of not being (and never expecting to be) "heard."

We were further able to identify resistance tactics that could not be observed in hearing transcripts exactly because they occurred outside of hearings. An archival approach would have mistakenly identified the public hearings as a failed deliberative environment-but a field methodology allowed us to observe that our participants oriented to hearings simply as a strategic point of leverage, but by no means the entirety of the deliberative field. Only from this vantage point could we see that the predictability of the hearing timeline produced organizational, educational, and tempo-setting effects within Surry's broader deliberative field, enabling locals to guard deliberative time and inspiring the production of new deliberative spaces (the hearing event became an opportunity to begin a discussion in someone's driveway, the hearing parking lot, the grocery store, at a child's school, or an opportunity to invite new stakeholders to a pre-hearing potluck). The field approach allowed us to reckon not just with the intrinsic value of public hearings, but with the way these hearings were assigned meaning and consequently acted upon by stakeholders as they made sense of and ultimately resisted ODEC's attempts to rezone. This reshaped our perceptions of the events, the campaign's outcomes, inter- and intra-community relationships, and the translation of values between stakeholder groups.

The use of field methodology also enabled us to observe that the type of strain and severity of strain experienced by community members as a result of the deliberative process may be deeply racialized. These observations merit further study on the racialized effects of environmental decisionmaking processes on small communities. The absence of the perspectives of Black community members is a shortcoming of this study, as the authors' direct contact was almost entirely with non-Black community members.

Finally, our findings also suggest that further attention be given to the deliberative backstage in scholarly work regarding environmental decision-making processes. Our case study illuminated the deliberative backstage as a rich environment for stakeholder discernment, stakeholder cohesion, and stakeholder conflict. In the case of Surry County, the deliberative backstage was the only site where the value of an obligatory public hearing process was observable, and the only site where the incredible strain of the deliberative process on the local community could be felt.

\section{CONCLUSION}

The Surry case demonstrates that small town deliberation is a timeintensive process, for which public hearings can be both a placeholder and a pace-keeper, despite their limits. Public hearings did not make residents feel heard, but they provided spaces and a timeline for concerns to be expressed, for insiders and outsiders to meet and build trust, and for the community to discern what it wanted and needed. And in the case of Surry, much needed additional time was purchased through the achievement of delays, postponed hearings, and lawsuits related to ODEC's illegal attempts to accelerate an already-accelerated process. The residents' clamoring for time cannot simply be understood as a strategic attempt to create bureaucratic drag. Surry had a right not just to the public hearing space, but to a public hearing timeline (and recompense for ODEC's illegal attempts to hurry it). We suggest that the whole deliberative landscape of communities be more often considered in discussions of the validity and value of the public participation process.

When Senator Henry "Scoop" Jackson, sponsor of the National Environmental Policy Act, spoke in support of the bill on the floor of the senate in 1969 he made it clear that the goal of the act was to ensure that "exceptions [to sound environmental policy] will have to be justified in light of the public scrutiny required by section 102" (Jackson, 1969). Public participatory processes are designed to do exactly that, and in the case of Surry's "No Coal Plant" campaign public hearings played an essential role in the process enabling both public deliberation and public scrutiny.

\section{DATA AVAILABILITY STATEMENT}

The original contributions presented in the study are included in the article, further inquiries can be directed to the corresponding author.

\section{ETHICS STATEMENT}

The studies involving human participants were reviewed and approved by Boston College Institutional Review Board. The patients/participants provided their written informed consent to participate in this study.

\section{AUTHOR CONTRIBUTIONS}

JC is the lead author. Both authors contributed substantially to this work. 


\section{REFERENCES}

Asen, R. (2017). Neoliberalism, the Public Sphere, and a Public Good. Q. J. Speech 103 (4), 329-349. doi:10.1080/00335630.2017.1360507

Buccino, S. (2020). Understanding Trump's Harmful Attack on NEPA, July 15, 2020. NRDC Expert Blog. Available at: https://www.nrdc.org/experts/sharon-buccino/ understanding-trumps-harmful-attack-nepa (Accessed October 7, 2021).

Buttny, R. (2010). Citizen Participation, Metadiscourse, and Accountability: A Public Hearing on a Zoning Change for Wal-Mart. J. Commun. 60 (4), 636-659. doi:10.1111/j.1460-2466.2010.01507.x

Buttny, R., and Cohen, J. R. (2007). Drawing on the Words of Others at Public Hearings: Zoning,Wal-Mart, and the Threat to the Aquifer. Lang. Soc. 36 (5), 735-756. doi:10.1017/s0047404507070674

Buttny, R. (2015). Contesting Hydrofracking During an Inter-governmental Hearing: Accounting by Reworking or Challenging the Question. Discourse Commun. 9 (4), 423-440. doi:10.1177/1750481315576842

Clarke, T., and Peterson, T. (2016). Environmental Conflict Management. Los Angeles, CA: Sage.

Cox, J. R. (2010). Beyond Frames: Recovering the Strategic in Climate Communication. Environ. Commun. 4 (1), 122-133. doi:10.1080/17524030903516555

Cox, R. (1999). "Reclaiming the "Indecorous" Voice: Public Participation by LowIncome Communities in Environmental Decision-Making," in Proceedings of the Fifth Biennial Conference on Communication and the Environment. Editors C. B. Short and D. Hardy-Short (Flagstaff, AZ: Northnern Arizonia University School of Communication), 21-31.

Cox Callister, D. (2010). Land Community Participation: A New "Public" Participation Model. Environ. Commun. 7 (4), 435-455.

Daniels, S., and Walker, G. (2001). Working Through Environmental Conflict: The Collaborative Learning Approach. Westport CT: Praeger.

Delicath, J. (2004). "Art and Advocacy: Citizen Participation Through Cultural Activism," in Communication and Public Participation in Environmental Decision Making. Editors S. Depoe, J. Delicath, and M. Aepli-Elsenbeer (Albany: SUNY Press), 255-266

Depoe, S., and Delicath, J. (2004). "Introduction," in Communication and Public Participation in Environmental Decision Making. Editors S. Depoe, J. Delicath, and M. Aepli-Elsenbeer (Albany, NY: SUNY Press), 1-10.

Endres, D. (2012). Sacred Land or National Sacrifice Zone: The Role of Values in the Yucca Mountain Participation Process. Environ. Commun. 6 (3), 328-345. doi:10.1080/17524032.2012.688060

Endres, D. (2009). Science and Public Participation: An Analysis of Public Scientific Argument in the Yucca Mountain Controversy. Environ. Commun. 3 (1), 49-75. doi:10.1080/17524030802704369

Hahn, J. (2020), Trump's NEPA Rollback Favors More Pollution and Less Community Input. Sierra: The Magazine of the Sierra Club. July 17, 2020. Available at: https://www.sierraclub.org/sierra/trumps-nepa-rollback-favorsmore-pollution-and-less-community-input (Accessed October 7, 2020).

Hart, R., and Dillard, C. (2001). "Deliberative Genre," in Encyclopedia of Rhetoric. Editor T. Sloane (Oxford, UK: Oxford University Press), 209-217.

Hendry, J. (2004). "Decide, Announce, Defend: Turning the NEPA Process into an Advocacy Tool rather Than a Decision-Making Tool," in Communication and Public Participation in Environmental Decision Making. Editors S. Depoe, J. Delicath, and M. Aepli-Elsenbeer (Albany, NY: SUNY Press), 99-112.

Hunt, K., Paliewicz, N., and Endres, D. (2019b). "The Radical Potential of Public Participation Processes: Using Indecorous Voice and Resistance to Expand the Scope of Public Participation," in Breaking Boundaries: Innovative Practices in Communication and Public Participation. Editors K. Hunt, G. Walker, and S. Depoe (Albany, NY: State Univrrsity of New York Press), 149-174.

Hunt, K., Walker, G., and Depoe, S. (2019a). "Introduction: From Public Participation to Community Engagement-And beyond," in Breaking Boundaries: Innovative Practices in Communication and Public Participation. Editors K. Hunt, G. Walker, and S. Depoe (Albany, NY: State University of New York Press), 1-17.

Jackson, H. (1969). 115 Congressional Record, 40,416.doi:10.1080/ 00306525.1969 .9634351

Johnson, T. (2019). The Dakota Access Pipeline and the Breakdown of Participatory Processes in Environmental Decision-Making. Environ. Commun.
Kinsella, W. (2004). "Public Expertise: A Foundation for Citizen Participation in Energy and Environmental Decisions," in Communication and Public Participation in Environmental Decision Making. Editors S. Depoe, J. Delicath, and M. Aepli-Elsenbeer (Albany, NY: SUNY Press), 83-98.

Koban, J. (2019). Ecological Restoration or Healing?: Conflicting Ontologies and Missed Opportunities in Public Debates Surrounding Mississippi River Gorge Restoration. Environ. Commun. 14 (5), 582-596.

Mando, J. (2016). Constructing the Vicarious Experience of Proximity in a Marcellus Shale Public Hearing. Environ. Commun. 10 (3), 352-364. doi:10.1080/17524032.2015.1133438

Middleton, M. K., Senda-Cook, S., and Endres, D. (2011). Articulating Rhetorical Field Methods: Challenges and Tensions. West. J. Commun. 75 (4), 386-406. doi:10.1080/10570314.2011.586969

Patterson, R., and Lee, R. (2000). "The Environmental Rhetoric of "Balance": A Case Study of Regulatory Discourse and the Colonization of Public," in Technical Communication, Deliberative Rhetoric, and Environmental Discourse. Editors N. Coppola and B. Karis (Stamford, CT: Ablex Publishing Corporation), 235-250.

Peterson, M. N., Peterson, M. J., and Peterson, T. R. (2005). Conservation and the Myth of Consensus. Conservation Biol. 19 (3), 762-767. doi:10.1111/j.15231739.2005.00518.x

Pezzullo, P. (2004). "Toxic Tours: Communicating the "Presence" of Chemical Contamination," in Communication and Public Participation in Environmental Decision Making. Editors S. Depoe, J. Delicath, and M. Aepli-Elsenbeer (Albany: SUNY Press), 235-254.

Pezzullo, P. (2007). Toxic Tourism: Rhetorics of Pollution, Travel, and Environmental Justice (Tuscaloosa, AL: University of Alabama Press).

Pezzullo, P. C., and de Onís, C. M. (2017). Rethinking Rhetorical Field Methods on a Precarious Planet. Commun. Monogr. 85, 103-122. doi:10.1080/ 03637751.2017 .1336780

Pezzullo, P., and Cox, J. R. (2018). Environmental Communication and the Public Sphere. 5th Edn. Thousand Oaks, CA: Sage Publications, Inc.

Scarff, K. (2021). Mapping Vicarious Proximity: Holistic and Dualistic Metaphors in a Mountain Valley Pipeline Public Hearing. Environ. Commun. 15 (4), 514-529. doi:10.1080/17524032.2020.1867602

Senecah, S. (2004). "The Trinity of Voice: The Role of Practical Theory in Planning and Evaluating the Effectiveness of Environmental Participatory Processes," in Communication and Public Participation Inenvironmental Decision Making. Editors S. Depoe, J. Delicath, and M. Aepli-Elsenbeer (Albany, NY: SUNY Press), 13-34.

Walker, G. (2007). Public Participation as Participatory Communication in Environmental Policy Decision-Making: From Concepts to Structured Conversations. Environ. Commun. A J. Nat. Cult. 1 (1), 99-110. doi: $10.1080 / 17524030701334342$

Walker, G. (2004). "The Roadless Area Initiative as National Policy: Is Public Participation an Oxymoron?," in Communication and Public Participation in Environmental Decision Making. Editors S. Depoe, J. Delicath, and M. AepliElsenbeer (Albany, NY: SUNY Press), 113-136.

Conflict of Interest: The authors declare that the research was conducted in the absence of any commercial or financial relationships that could be construed as a potential conflict of interest.

Publisher's Note: All claims expressed in this article are solely those of the authors and do not necessarily represent those of their affiliated organizations, or those of the publisher, the editors and the reviewers. Any product that may be evaluated in this article, or claim that may be made by its manufacturer, is not guaranteed or endorsed by the publisher.

Copyright $\odot 2021$ Carroll and Bsumek. This is an open-access article distributed under the terms of the Creative Commons Attribution License (CC BY). The use, distribution or reproduction in other forums is permitted, provided the original author(s) and the copyright owner(s) are credited and that the original publication in this journal is cited, in accordance with accepted academic practice. No use, distribution or reproduction is permitted which does not comply with these terms. 


\section{APPENDIX}

\section{Abridged Timeline of Campaign Events}

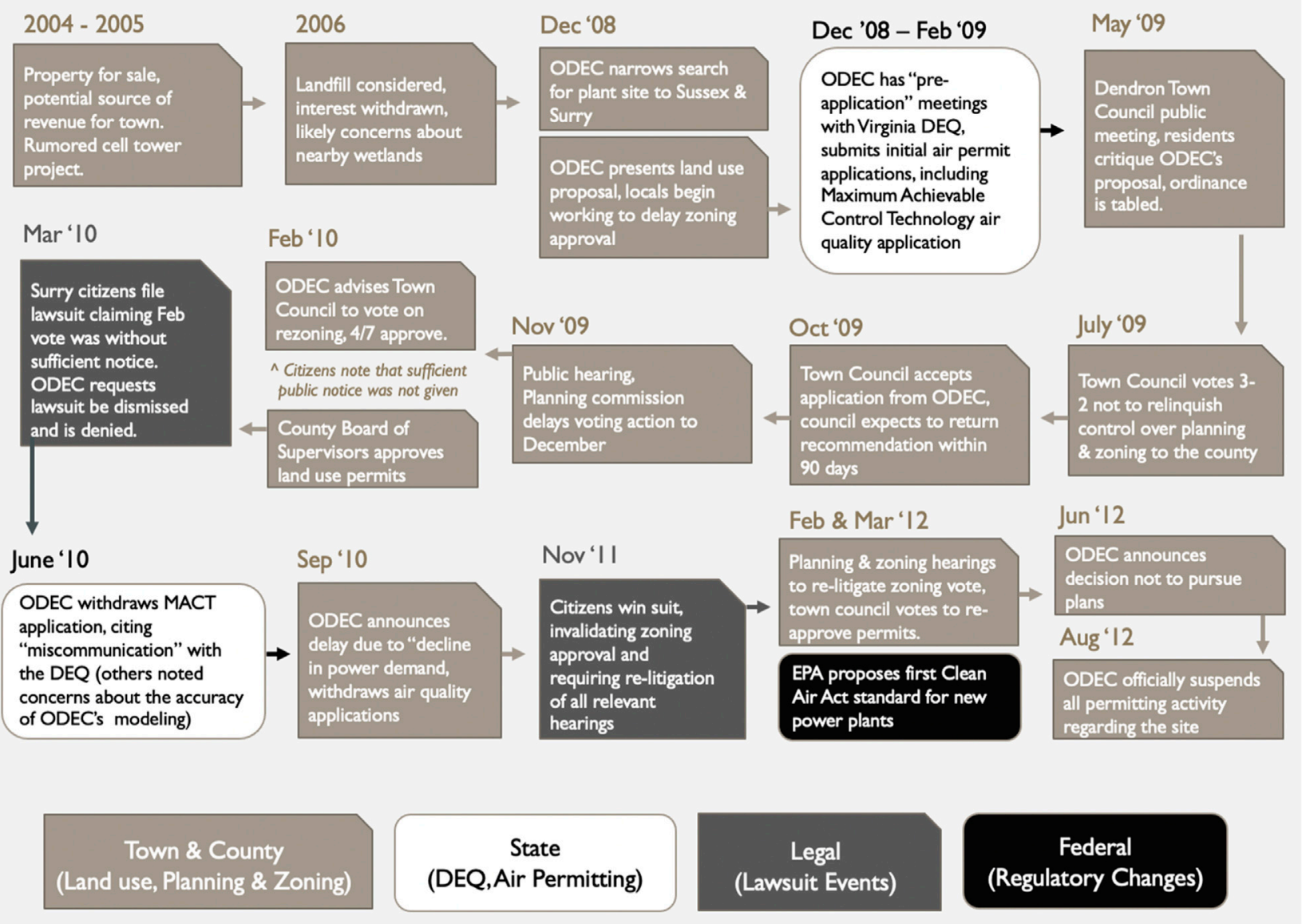

Appendix A | Abridged timeline of campaign events. 